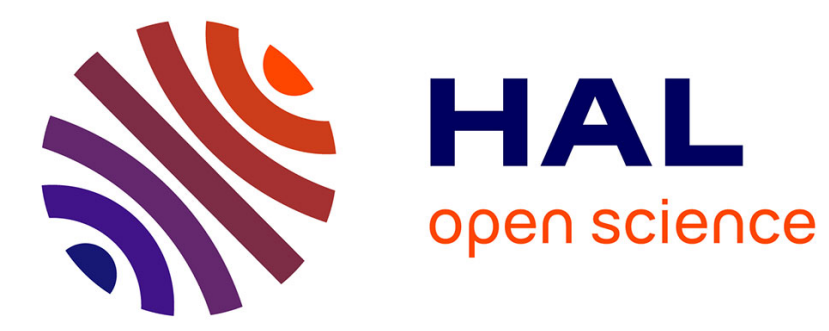

\title{
Performing for Peace and Social Change in Africa's Great Lakes Region
}

\author{
Maëline Le Lay
}

\section{To cite this version:}

Maëline Le Lay. Performing for Peace and Social Change in Africa's Great Lakes Region. Theatre Research International, 2021, 46 (1), pp.23-38. 10.1017/S0307883320000565 . halshs-03089834

\section{HAL Id: halshs-03089834 \\ https://shs.hal.science/halshs-03089834}

Submitted on 28 Dec 2020

HAL is a multi-disciplinary open access archive for the deposit and dissemination of scientific research documents, whether they are published or not. The documents may come from teaching and research institutions in France or abroad, or from public or private research centers.
L'archive ouverte pluridisciplinaire HAL, est destinée au dépôt et à la diffusion de documents scientifiques de niveau recherche, publiés ou non, émanant des établissements d'enseignement et de recherche français ou étrangers, des laboratoires publics ou privés. 


\section{Performing for Peace and Social Change in Africa's Great Lakes Region ${ }^{1}$}

International aid has influenced and, in part, shaped the artistic sector in Africa's Great Lakes region (DRC, Rwanda, Burundi) since the 199os, a period marked by numerous conflicts and mass violence. Due to NGOs' programmatic foci, artists performing for social change are increasingly compelled to focus on reconciliation and conflict resolution, generating political awareness and bringing about social change, healing and peacemaking. Through a comparative analysis of European and local productions on the genocide this article asks, how and why does an 'NGO-style theatre' develop a specific audience in the region? How have themes such as mass violence, inter-ethnic conflict and social cohesion become the main concerns of the territory's theatre? How do performances made and/or sponsored by NGOs challenge not only theatre's form, its social stakes and functions, but also the conception of its audience and the relationships between actors and spectators?

\section{Introduction}

The first images that spring to mind when thinking about Africa's Great Lakes region are those of war, mass violence and genocide. Together they generate an entangled, messy, impenetrable idea of the region. ${ }^{2}$ Although many local artists lament this simplistic and biased impression, both local and foreign artistic productions draw on the turbulent history and contemporary politics of this area. ${ }^{3}$ Artists depict themes of war, mass violence and conflict that have plagued the region for over three decades for diverse reasons: to soothe pains, cure traumas and/or generate citizen awareness. This article is part of an ongoing research project on the politics of contemporary theatre production in east-central Africa, commonly referred to as 'Africa's Great Lakes', a territory that includes eastern Congo (i.e. the DRC provinces of North Kivu and its Q2 capital city, Goma, and South Kivu and its capital city, Bukavu), Rwanda (Kigali), and Burundi (Bujumbura). I am interested in the ways in which art can be reconfigured in complex, interconnected societies marked by repetitive conflict and traumas that are difficult or dangerous to deliberate openly and directly, and where imagining the future can be a supremely delicate act. Through comparative analysis the article asks, how does theatre made and/or sponsored by non-governmental organizations (NGOs) in a (post-)conflict sociopolitical context challenge not only theatre's practice and form, its uses, social stakes and functions, but also the conception of its audience and the relationships between actors and spectators? How and why does an 'NGO-style theatre' occupy a particular space and develop a specific audience, rooting itself in the Great Lakes region? How have topics such as genocide, mass killings and 
social cohesion become the main concern in the region's theatre and literary scenes and how have these been addressed in local and European productions?

In order to discuss how philanthropic organizations and artists operate in these three neighbouring countries that share a common and convoluted past, the article begins with a historical overview of international aid in the region. I then show how the gory history of this region has inspired theatre artists based in Europe. As this European theatre, labelled 'genocide theatre' by Annick Asso, ${ }^{4}$ bears little similarity to local productions in the Great Lakes, it is interesting to compare the two to throw light on audience politics, and discrepancies in modes of production and artistic content. Subsequently, I compare two local projects run by two well-established philanthropic organizations that work with artists: Radio La Benevolencija, a Dutch NGO working in the three countries, and a cluster of four state-run and local organizations (Goethe Institut Kigali, the French Institute in Rwanda, the Rwanda Arts Initiative and Yole!Africa Goma). Although these organizations do not label themselves 'philanthropic' per se, I consider them as such, since their projects are committed to promoting peace and reconciliation as a conduit to development. I describe the challenges faced by these NGOs in a conflict-torn region, where aid shapes not only the entire economic sector but also the priorities of the artistic stage. Artists working with these philanthropic organizations (mostly, but not exclusively, NGOs focused on reconciliation, conflict resolution, dialogue and reparation) engage in 'performing for social change'; that is, supporting peacemaking through artistic practice and production. Referring to misunderstandings between NGOs and local artists, this article concludes with a discussion of discrepant conceptions of theatre: the use of fiction narrative (storytelling) and the symbolic dimension (metaphor). I show how art in the Great Lakes region is mainly understood in terms of fictional narrative and is based on mimesis rather than poetics, seldom relying on the symbolic dimension.

This article is based on participant observation and data collection in the literary and theatre sectors, conducted during several research stays in the Great Lakes. I conducted initial fieldwork in the region in 2015, primarily in eastern Congo, building on intuitions from previous research on performances in southern Congo. ${ }^{5}$ I also conducted research in Burundi among aid organizations that work closely with partners in the DRC. In 2018, 2019 and 2020, I spent thirteen months between Goma, Bukavu, Kigali and Bujumbura, continuing my fieldwork on the literary scene and the theatre sector connected to government and non-government projects aimed at conflict resolution and social cohesion in the region.

\section{Historic mapping of philanthropic organizations in Africa's Great Lakes}

Aid has had a significant influence on the DRC, Rwanda and Burundi since their independence (in the 1960s). The history of these countries can be demarcated into two periods: before and after the 1994 Rwandan genocide of Tutsi people. The international community's refusal to acknowledge simmering tensions between ethnic groups - compounded by the fact that international actors were evacuated from 
Rwanda in the genocide's early days - impacted Rwanda's relationship with the rest of the world, especially Western countries, who, in effect, allowed the mass killings to happen. The genocide also had a significant effect on the geopolitics of the region, disrupting relations between Rwanda and its neighbours, especially the DRC. Furthermore, it prompted the protracted and large-scale migration of refugees all over the region, resulting in closely knit networks in the aid and artistic sectors in the DRC, Burundi and Rwanda, as I will delineate below.

The DRC was supported by Western aid until 1990, when Mobutu's then allies, infuriated by his growing attacks on democracy, cut off all state and non-state funding that supported his regime. From then on, the country descended into chaos and experienced a severe economic downturn. Theodore Trefon, a political scientist specializing in the DRC, notes that this period was characterized by the spontaneous development of civil society organizations, local associations and NGOs that emerged to cope with the crisis of the failing state. ${ }^{6}$ In 1997, Laurent-Désiré Kabila overthrew Mobutu's regime and promoted a politics of autonomization not only from his past allies, Rwanda and Uganda, but also from Western countries who were not welcomed back to pursue cooperation programmes. ${ }^{7}$ After his assassination in the year 2000, the country reopened and international NGOs and foreign organizations were encouraged to return. Joseph Kabila, who succeeded his father, welcomed international aid. The NGOs' purposes were twofold: rebuilding the country, which was in an appalling situation, and reconciling war-torn communities who were distrusting, fearful, traumatized and resentful, particularly in the eastern part of the country.

Until 1993, Burundi was ruled by a series of authoritarian regimes (Michel Micombero, 1966-76; Jean-Baptiste Bagaza, 1976-87; Pierre Buyoya, 1987-93) that discouraged the creation of associations, local cooperatives and NGOs. ${ }^{8}$ After coming to power in July 1993, Melchior Ndadaye's government planned civil society reforms to encourage development. However, he did not have the chance to apply these reforms. His assassination in October 1993 triggered a protracted war that plagued Burundi for a decade. Although Buyoya, the Tutsi president who subsequently ruled the country from 1996 to $2003,{ }^{9}$ did not initially support foreign NGOs, he eventually allowed them to establish a presence in Burundi. He especially supported NGOs specializing in reconciliation and peacemaking as he was aware that the entire region was at high risk of another genocide. ${ }^{10}$ As he succeeded two Hutu presidents, Ndadaye and Cyprien Ntaryamira, both assassinated, in 1993 and 1994 respectively, he was especially sensitive to ethnic conflicts and therefore initiated a series of political measures to prevent further crimes, such as ensuring ethnic balance in the public sector and favouring dialogue for reconciliation and peacemaking. ${ }^{11}$ Consequently, both in the DRC and in Burundi, the 1990 s was a decade marked by international NGOs' return to the region.

Before the genocide, Rwanda was classified as one of the poorest countries in the world and consequently it was one of the largest aid beneficiaries in Africa. ${ }^{12}$ Apart from alliances with the World Bank and international development agencies and the presence of NGOs, numerous bilateral cooperations existed between Rwanda and 
several European countries until the 1990s. During the genocide, NGOs played numerous functions. While several were politically ambiguous, others attempted to warn the international community about an impending genocide. ${ }^{13}$ Simultaneously, a great number simply fled the country when the genocide began, some resettling in Goma, DRC (formerly Zaire) in the Turquoise Zone opened up by the French Army. Paradoxically, French organizations active in the zone welcomed and even cared for many perpetrators of the genocide who were fleeing their country due to fear of retaliation. ${ }^{14}$

Since his accession to power after ending the Rwandan genocide in 1994, Paul Kagame liberalized the economy to attract foreign investors and develop the country. He succeeded in gaining support from many Western donors, as shown by Rwanda's rank on the DoingBusiness2018 index (among the top three in Africa). ${ }^{15}$ Abroad, the country is labelled 'the good student', ${ }^{16}$ the 'champion', or even the 'African dragon' or 'African Singapore'. ${ }^{17}$ However, this recent prosperity parallels a growing suspicion of international aid organizations due to their ambiguous role during the genocide. In March 1995, two-thirds of NGOs were either ordered to leave the country within a week or were summoned to the Rwandan Governance Bureau to negotiate new terms for their projects. ${ }^{18}$ Since then, it has been difficult for NGOs to work in Rwanda as the government closely controls their activities. Despite these issues, many local and international organizations and NGOs in the DRC and Burundi focus today on issues of justice (reconciliation, peacemaking) or mental-health care (trauma healing), that favour cooperation with the artistic sector, specifically the theatre. I will now demonstrate the interrelation between art - more specifically fiction - and trauma, and the supposed abilities of the former to address and heal the latter.

\section{At a global geopolitical level: turning to a transitional-justice approach}

As demonstrated above, the 'post-conflict' situation of the Great Lakes region attracted

philanthropic organizations specializing in conflict resolution and most of them followed a transitional-justice agenda. Increasingly used in a growing number of countries, ${ }^{19}$ 'transitional justice refers to the ways countries emerging from periods of conflict and oppression address large-scale or systematic human rights violations so numerous and serious that the normal justice system cannot provide an adequate response. Transitional justice is rooted in forms of accountability and redress for victims' ${ }^{20}$ These comprise official and unofficial arrangements such as popular courts implemented in post-apartheid South Africa; and less formal legal arrangements aimed at conflict resolution, reconciliation and peace. Peace-building consultant resolution with NGOs. ${ }^{21}$ She expounds on her time with the NGO RCN Justice \& Démocratie and her own programme Re-imagining Peace, a title that highlights 'the importance that should be attached to the symbolic dimension and local imaginaries in every process of conflict transformation'. ${ }^{22}$ She affirms that comprehending the 
sensitive to numerous social meanings that we do not usually perceive but that in reality make or unmake social contracts. ${ }^{23}$ This assertion illuminates the reasons for the recent art-focused trend in peace-building projects. The transitional-justice-oriented aid framework with its related arts focus has increasingly been applied globally, and, in general, has gained local populations' trust and support. In Rwanda, international NGOs have fully settled in, with the explicit goals of strengthening social cohesion and promoting 'culture', understood as 'artistic practice and production'. Search for Common Ground (SFCG) and La Benevolencija are two such organizations, both working simultaneously across the DRC, Rwanda and Burundi.

The story of the American NGO SFCG in the region starts in 1997 in Burundi when the country was in the midst of a civil war. At that time, SFCG initiated a radio programme, comprising a number of sketches called Umubanyi niwe muryango (Our Neighbours Are Our Family) under the auspices of Studio Ijambo, the country's first humanitarian radio station. Thought to encourage reconciliation between warring parties, these sketches or radio dramas consisted of recorded dialogues in serial form. The production of these radio drama serials is as prolific as it is long-running: in early April 2015, the troupe was up to episode 909, airing two episodes a week. The story revolves around two neighbouring families, who come to build very strong ties. One is Hutu, the other Tutsi, but we don't know which is which, a deliberate ambiguity that aims to transcend ethnic divisions and surpass prejudices. This dramatic family-saga format, with its archetypal characters of star-crossed lovers modelled on Shakespeare's Romeo and Juliet divided and united by conflicts, was then exported in 2006 to Congo, where it continues to be popular under the Swahili name Jirani ni ndugu (Your Neighbour Is Your Brother). The slogan is still used by SFCG to introduce its method wherever it settles. The underlying idea of once-warring neighbours coming together in basic human ways was and is viewed as highly adaptable, provided that problems between neighbours, in the broadest sense of the term, have been central to the conflicts. Due to the interconnected nature of the conflicts that have persistently threatened human rights in the entire region since the 1990s, the term jirani ni ndugu has come to stand for any conflict-resolution drama widely broadcast in the Great Lakes region with unwavering popular success. ${ }^{24}$ Building on Boalian methods, SFCG also developed a live performance genre that it called 'participatory theatre'. This method, common to all three countries of the Great Lakes region, mainly uses forum theatre, specifically the 'spect-actor', to stimulate social change through mental transformation. Significantly, this re-enactment of the real (either historical events or ordinary scenes) is a common feature of practitioners based in Europe and Africa's Great Lakes region, although it is realized through different means in each context.

\section{Imagining a post-disaster future}

The genocide in Rwanda and the violent wars in Burundi and DRC have inspired many artists settled in Europe where diasporic communities from the Great Lakes countries are 
working on these issues over the last two decades first presented shows aimed at European audiences. Among the plays dealing with the genocide are the famous theatre documentary Rwanda 94 by Groupov (Liège, 2000), the controversial Hate Radio by Milo Rau (Zurich, Cologne and Berlin, 2013), and more recently the twofold drama Hagati Yacu and Ejo N'ejo Bundi by Compagnie Uz et Coutûmes (Uzeste, France, 2014 and 2018). ${ }^{25}$ Other performances deal with war in Congo, such as Africare by Lorent Wanson (Mons, Belgium, 2007), and the deadly consequences of war on women in Burundi (Les recluses by French-Ivorian Paris-based playwright Koffi Kwahulé, staged by Sébastien Géraci, Cie la Troup'ment-Le Théâtre du Risque, Petit Théâtre de Grenoble in France, 2011). Even if these projects often involve artists from the targeted countries, the stakes of staging a play about these issues in Europe differ dramatically from those of shows staged in the affected countries themselves. Exploring the gap between European and local artistic agendas is crucial to better understand the stakes in local productions, especially because their productions often appear less striking at first glance than their better-funded European-made counterparts.

Most European productions explicitly aim to affect their audiences through a deeply gripping and consciously constructed dramatic aesthetic. Rau's Hate Radio, for example, was re-created on the set of the radio studio of Radio Télévision Libre Mille Collines (RTLM) - known for its critical and evil role in promoting and organizing the genocide - to move and unsettle the audience, which the stage director termed an 'aesthetics of re-enactment'. ${ }^{26}$ Rau's discourse about his polymorphous stage work indicates that his theatre productions are first and foremost dedicated to a Western audience that he considers lethargic, numb in its privilege. His 're-enactments' are 'social plasticities' that constitute opportunities to reintroduce politics into everyday life and raise the level of political consciousness in Europe. Rau violently appeals to the audience's senses in order to shake them up and disturb a pacified world where 'absolutely everything is organized in a capitalistic way and accommodated according to neoliberal concepts'. ${ }^{27}$ Q4 Significantly, the shocking effect of Hate Radio is not an isolated case in the genre 'theatre of genocide' conceived in Europe. Most of the shows mentioned above deployed violent aesthetics in a conscious left militant move to make Europeans European-made shows dramatically differ from shows about mass violence staged in the Great Lakes. Often, these European performances are considered inappropriate even for local audiences, either because of their politico-aesthetic choices (for instance, hiring non-professional actors to be as 'realistic' as possible, as in Lorent Wanson's Africare, or because they risk reactivating trauma). ${ }^{28}$

Against these aesthetics, philanthropic organizations focusing on art and culture budgets and audience reception. Both case studies that I present below focus on transboundary projects for reconciliation: the first one run by an NGO, Radio La 


\section{Performing genocide and mass killings}

La Benevolencija is a Dutch NGO founded in 2002 that produces media projects to empower people suffering from hate-based violence. While its headquarters are in Amsterdam, it works exclusively in the Great Lakes with missions in Rwanda, Burundi and the DRC, where local staff work on media communication - mostly through broadcast dialogues and increasingly via live performance - in order to increase awareness about hatred and exclusion mechanisms and ultimately help reconcile formerly inimical communities. La Benevolencija took inspiration from La Benevolencija Sarajevo, a local organization that played a humanitarian role during the Bosnian war (1992-5). The NGO was part of the city's Jewish community that was professedly neutral. Consequently, its members were used by warring parties as trusted interlocutors. In 2002 in Rwanda, Georges Weiss, the media professional from Vienna who founded La Benevolencija in Sarajevo in 1995, met the American psychologist Ervin Staub, a Hungarian-born Jew who survived the Holocaust as a child. Consequently, the NGO La Benevolencija Humanitarian Tools was founded on Weiss's and Staub's post-genocide experience and research (Bosnia for Weiss, Shoah for Staub). Drawing on the experiences of Staub and a trauma expert, Dr Laurie Pearlman, La Benevolencija crafted its own tools for conflict resolution for Africa's Great Lakes Region, working for reconciliation on multiple levels: both grass-roots communities and national leaders. Its agenda is broad, designed to be tailored to any post-conflict society. Theirs is 'an agenda of sanity, empathy and mutual help among those who are the target of hate speech, as well as among societies that have suffered its consequences' ${ }^{29}$

One of the challenges for this organization rooted in European history has been to adapt their work to the context of the Great Lakes without imposing an exogenous model on local African narratives, a problem that its heads are aware of. ${ }^{30} \mathrm{La}$ Benevolencija tries to avoid being too interventionist by exclusively recruiting local staff who are in charge of both writing the dialogues for their radio drama series (in DRC it is called Kumbuka Kesho, meaning 'remember tomorrow' in Swahili) and managing the local missions. In addition to their local staff, the NGO works extensively with resident communities, developing committees concerned with specific issues that are developed into radio dramas. These bystanders, as La Benevolencija calls them, are expected to reflect upon the NGO's social cohesion and peace-building teachings in their daily lives. They are encouraged to participate in focus groups and seminars to help La Benevolencija's staff improve story scenarios that in turn influence the NGO's conflict-resolution approach. In other words, from a Boalian perspective, if the bystander's figure accompanying the radio dramas was applied to live performance, he would be the equivalent of the 'spect-actor', an actor becoming the spectator. The Bystander would be akin to a spect-actor-in-the-making who guarantees the broadest participation of target grass-roots communities.

However, although La Benevolencija strives to prevent top-down impositions of storylines and conclusions, any dialogue proposed by the writers in consultation with local committees must be approved by the headquarters in Amsterdam and by the 
'scientific team' in the US before being finalized for broadcast. ${ }^{31}$ The script, therefore, has to be written in French to be approved, before the play can be performed, recorded and broadcast in every place's lingua franca (Swahili in the Kivus, Kinyarwanda in Rwanda, Kirundi in Burundi), the actors themselves translating the script from French (or English, in Rwanda) to the respective languages. The radio dramas are squarely focused on the messages conveyed, and their structure is predetermined by La Benevolencija. The messages - their content and intention - are considered by the NGO to be far more important than any aesthetic or formal considerations, despite the fact that what constitutes 'narrative form' may vary tremendously from one cultural context to another. La Benevolencija's handbook makes no mention of aesthetic considerations, and these are also absent from its principal inspiration - Staub's Overcoming Evil: Genocide, Violent Conflict and Terrorism, which summarizes his method. ${ }^{32}$ Neither the NGO's staff, its regional heads of missions nor its theoreticians in the US seem to be concerned with aesthetic criteria such as the plot's originality, character complexity, mise en scène, poetry, metaphor or any kind of symbolism. Although, in order to be 'entertaining' - and therefore as effective as 'educational entertainment' - art should at least be soundly structured and formally pleasing, their approach is first and foremost 'edutainment', a portmanteau term signifying the combination of education and entertainment through fiction. ${ }^{33}$ The programmes' poor aesthetic quality may explain why artists who started working with them have either quit (due to a lack of opportunities for creativity) or stayed at La Benevolencija but have stopped writing their own texts. Loffe Chirali, for example, who used to be a permanent writer at La Benevolencija Bukavu and whose play was lauded in a festival of radio dramas in France in 2009, ${ }^{34}$ explained to me that he is unable to write independently any more; the plays that he is obliged to write every day having stifled his creativity.

Subtitled 'la culture orale comme moteur intergénérationnel de réconciliation dans la région des Grands Lacs' ('oral culture as a transgenerational driving force for reconciliation in the Great Lakes region'), DigiTales across Borders is a collective project led by the Goethe Institut Kigali, the Institut Français in Rwanda, and two local associations focused on promoting art and 'empowering youth' through art: Rwanda Arts Initiative (RAI) based in Kigali and Yole!Africa based in Goma, a local cultural centre dedicated to the promotion of visual arts, especially cinema. ${ }^{35}$ DigiTales across Borders is funded by the Fonds Culturel Franco-Allemand (French-German Cultural Funding). The DigiTales project is based on two underlying assumptions: first, that yesterday's storytellers, termed the 'gatekeepers of history', ${ }^{36}$ are the equivalent of the young spoken-word artists of today; second, that the seeds of reconciliation and social harmony lie in traditional tales. It additionally assumes that France and Germany share a common cultural history as the driving forces for post-war reconciliation following the Second World War. This third assumption permitted the organizations' joint application for Franco-German funding. The project began by organizing two workshops of artists from the three countries. The main goal was to extract the essential substance of reconciliation from these cultures, and to craft it into an artistic form; that is, fiction (a story, crossing tale and slam/spoken word) optimally performed in an 
artistic manner (with music, dance and poetry). The project was launched at the first workshop organized in Goma in June 2018. According to its website,

in a logic of transcending the borders in the Great Lakes, yesterday's tellers and young spoken word artists met during a week-long workshop in Goma, in Yole!Africa's office, under a week of workshop on the reconciliation values and the importance of preserving cultural heritage. The Rwandan, Burundian and Congolese artists shared and developed texts and tales on reconciliation and the importance of preserving cultural heritage. ${ }^{37}$ 
In his scathing review of the project, the artist referred to the notorious 'Opération Turquoise' launched by the French government in July 1994 after millions of Tutsi had already been killed. Initially meant to be a 'humanitarian corridor' to save persecuted Rwandans, the 'corridor' became an exit path for killers fleeing retaliation by the Tutsi rebel army under Paul Kagame, who later became, and still is, the president of Rwanda. This publication was, therefore, quite shocking for the organizations whose representatives, working in former colonized countries, were aware of these issues and did not intend to reproduce the tragically unequal relations inherited from colonialism. Moreover, everyone - the artists and the representatives of international organizations - know that the Goethe Institut and the Institut Français are often, in many African countries, the main places that offer a space for critical thought and artistic creativity and experimentation, something that the artist himself acknowledged in his text. ${ }^{40}$

However, what the organizers neglected to take into account was the strong desire for autonomy that has characterized Rwanda's cultural spheres since the genocide and which has been increasing since, as has Rwanda's positive image of a 'self-built' phoenix country. This will for independence is shared by all Rwandan artists who are acutely aware of postcolonial issues, both in theory and in practice. Another factor that the DigiTales implementers neglected to consider was psychological disturbance among participants, a risk that cross-border projects always run. They knew that the Rwandan spoken-word artist's allegation of neocolonialism was not the only reason for his abrupt departure from the project. He also complained about the low artist fees, but above all he admitted that he was upset after returning to his country of birth, where he had spent his childhood. ${ }^{41}$ The spoken-word artist, half-Rwandan and half-Congolese, had lived in Goma until 1994. As a child, he had to flee to Rwanda to escape the killings that were being perpetrated on the other side of the border, in the former Zaire. Consequently, in Goma, he was haunted by memories of his past. Moreover, one can easily imagine how disturbing it must be to be asked to return 'home' by foreign organizations. In his text he modestly spells out his own way of coping with the trauma that affected Rwandan society after the genocide, manifesting as episodes of crisis known more commonly as post-traumatic stress disorder (PTSD). ${ }^{42}$

\section{What theatre means in philanthropic peace-building programmes}

Although these two case studies do not seem to have much in common, not only in their nature - one being a temporary project run by a cluster of organizations, the other being a sustainable organization, an NGO - but also in the form of the dramas and performances they create, the two projects share the common goal of promoting peace and healing through drama. Additionally, both La Benevolencija and DigiTales partake in a common understanding of theatre's potential to achieve social transformation. In other words, they possess a real faith in performativity, the will to believe that reconciliation and eventual peace between formerly antagonistic communities staged in dramatic pieces will occur in reality in the future. Through radio dramas, La Benevolencija expects the audience to mimic in real life the 
characters embodied by the actors, considering that the re-enactment of a conflict followed by its resolution in drama will lead to actual change offstage. Focusing on narratives via storytelling (either as tale or as spoken word), the DigiTales Project also shares this faith. In other words, what makes art relevant to both projects is fiction and what appeals to them in fiction is mimesis. Although Jean-Marie Schaeffer, a researcher specializing in aesthetic philosophy, differentiates between fiction and mimesis, ${ }^{43}$ here fiction is commensurate with mimesis, more or less reflecting the real. What makes fiction especially effective for addressing difficult and sensitive issues such as violent conflict and trauma is its double and ambivalent nature: fiction allows simultaneously for mimesis and distance. While defining the specificity of fiction, Schaeffer stresses its powerful paradoxical force:

Fiction is this domain which is neither reality nor pure myth. It is what we can play with without getting harmed. If we can play with danger and if everybody wants to play with danger, it is because through fiction the human being can mentally live out situations that are either appealing or traumatic without having to pay the price and thereby has the opportunity to benefit from situations he would rather avoid in the future or recognize before they transpire. ${ }^{44}$

It would, however, not be fair to state that these two projects' organizers and implementers were exclusively focused on storytelling and thus insensitive to the symbolic dimension of performance and fiction, their possible poetry, and metaphorical meaning. From the first workshop to the second, the DigiTales project paid more attention to aesthetic considerations, enriching the tale and spoken-word performance with dance and music - artistic forms better related to poetry than to fictional prose. ${ }^{45}$ As far as La Benevolencija is concerned, interviews with some of its implementers based in Bukavu indicate that they were sensitive to the symbolic or aesthetic dimension of the performances, although they feared its capacity to disturb audiences. Accordingly, the NGO preferred safe mimetic narratives. While discussing stage productions by the Belgian director Frédérique Lecomte, head of Théâtre \& Réconciliation, a theatre company and association working in conflict areas (mostly the Great Lakes region), they conceded that her show added value to their work due to the symbolic dimension of music and choruses that she always inserts in her performances, and due to visual effects such as the collective movement of actors like human waves and playing with fabrics to signify burial shrouds or injuries: ${ }^{46}$ 'I saw people crying', said one of the implementers based in Bukavu, South Kivu, 'but sometimes, [spectators] also say that it is too much emotion, too violent to bear'. ${ }^{47}$ Executives in Bukavu and Bujumbura said that some spectators expressed not only concerns about the purpose of re-experiencing trauma in a context that offered no concrete programme for addressing the agony that people have lived through, but also the need to carry on living. ${ }^{48}$ Their observations suggest NGOs' underlying concerns regarding their (in)ability to deal with the unpredictability of a given audience's reaction to a performance. The fundamental question that begs answering is therefore this: as NGOs working for communities' wellness or 'development', how can they best 
prepare for and deal with the unsettling potential of certain kinds of aesthetically and symbolically rich performance?

\section{Conclusion}

When one observes from a comparative perspective, on the one hand the successful use of artistic genres such as theatre and performance in humanitarian work, and on the other the recurrence or even permanence of the peace issue (through repeated calls for reconciliation and social cohesion) in artistic creations made in this region, it is worth asking what in art makes its association with peace building possible. The case studies presented here seek to identify the specific feature in performance that enables cultural and social actors to use it as a powerful and reliable implement for peace building. By drawing on theatre's capacity to stimulate change, humanitarian aid attempts to work at the level of imagination to prompt positive transformation. For example, both Felwine Sarr, one of the major thinkers of decolonial thinking today, Q6 and Vianney Bisimwa, programme manager for the NGO Search for Common Ground in Mali (having been office manager in Goma) and director of communication for the Amani music and slam festival in Goma (amani means 'peace' in Kiswahili), agree on the importance of the symbolic dimension and the need to reinvest in the African imagination. Sarr, a professor of economics at the University Gaston Berger in Saint-Louis du Sénégal and co-organizer of the Ateliers de la Pensée in Dakar, is known for his defence of the importance of art and literature in fostering a new imagination. His essay Afrotopia, which has become a key reference in the African and Afro-diasporic intellectual milieux, builds on Cornelius Castoriadis's political conception of the 'imaginary institution of society', in order to build an active utopia that he calls 'Afrotopia':

Afrotopos is the atopos of Africa: this place not yet inhabited by this Africa that is coming. It has to be invested with thought and imagination ... Thought, literature, music, painting, visual arts, cinema, television series, fashion, popular songs, architecture and the impetus of the cities are spaces where the future forms of individual and social life take shape and shape themselves. ${ }^{49}$

Bisimwa, who is one of the founders of the Amani festival, which is partly funded by NGOs working in the region, explains that the major challenge of the festival is to transform the way Congolese look at themselves and their society, and thus the way others look at them:

We are doing this festival because we believe that one of the answers to violent conflict is to create hope. And I don't think you respond to despair by turning inward. All we have to do is show that we are not lost, that we can come together, that we can unite around what we have in common. ${ }^{50}$

For these two cultural entrepreneurs who are influential at a national and continental level, 
of looking' advocated by Bisimwa. Music, literature, performance, books and intellectual talks can be tools for stimulating this paradigm shift if a turn is made towards different kinds of narrative - through either fiction or meta-artistic discourses on what it means to hold an artistic event such as a music and slam festival in a war zone.

However, especially in regions of conflict, it is also worth asking to what extent artistic performances shape the imagination by asserting the 'right' direction that should be taken, especially when initiated by foreign institutions. This is the limitation that the dissident spoken-word artist from the DigiTales project indirectly pointed to. His scathing criticism of the project astutely shows how the universally shared and collectively implemented peace-building goal has been stipulated as an absolute (as 'development' has been, as Sarr reminds $\mathrm{us}^{51}$ ) promoted through 'international' agendas made by foreign institutions, notably former (neo-)imperialist powers which used to rule these countries or at least interfered in their political systems for the sake of cooperation. This long-standing foreign presence does not suit the recent decolonial trend in the intellectual milieu that has been on the ascent everywhere, especially in regions characterized by a strong NGO presence. In Africa's Great Lakes region, a territory that has undergone conflict, post-conflict and post-genocide conditions, not only has this presence become systemic, replacing states in many functional aspects of society, but also it is still associated with the fresh memory of times when foreign intervention failed to restore peace or fight injustices and occasionally went astray on a dark, violent path.

1 I would like to thank Assumpta Mugiraneza from IRIBA Center, Kigali; Caroline Foujanet from Institut Français du Rwanda; and Johan Deflander from La Benevolencija Amsterdam/Nairobi for providing much of the rich, useful information and material that made this article possible. I am also deeply

3 For instance, the famous Congolese choreographer Faustin Linyekula in Art in Troubled Times wonders when Africans might, if they feel like it, speak of flowers. Sean O'Toole, 'Coming through Slaughter' in Lien Heidenreich-Seleme and Sean O’Toole, eds., and Gabrielle Guy, design, Über(w)unden: Art in Troubled Times (Auckland Park: Jacana Media Ltd, 2012), pp. 204-211, here p. 209. See his stance in this video: www.youtube.com/watch?v=ZlKVbVlFBYI, accessed 5 May 2019. During a conversation with the audience after the performance of his vaudeville-like play Peau de caméléon, Ghislain Kabuyaya, a playwright and spoken-word artist from Goma, linked his desire to speak about love and to be funny, to this time of 'atrocities' in the Kivus, saying that people need love and humour (personal fieldwork journal, Goma, 23 March 2019).

4 Annick Asso, Le Théâtre du Génocide: Shoah et génocides arménien, rwandais et bosniaque (Paris: Honoré Champion, 2013).

5 See Maëline Le Lay, 'La parole construit le pays': Théâtre, langues et didactisme au Katanga (République démocratique du Congo) (Paris: Honoré Champion, 2014).

6 According to Trefon, 'neighbourhood associations, local NGOs and community-based solidarity 
social and economic subsistence'. Theodore Trefon, Congo: La mascarade de l'aide au développement (Louvain-la-Neuve: Academia-L'Harmattan, 2013), p. 157, trans. Michaela Raimo.

$7 \quad$ He labelled this autonomization process kujisaidia wenyewe in Kiswahili, meaning 'relying on oneself.

8 Describing the change of government in 1993, Reyntjens writes, 'In the past, political regimes have been deeply suspicious of any non-governmental structure; this is how they made considerable efforts to impose state control over cooperatives in order to prevent civil society from developing autonomous centers of economic power. This is part of a long authoritarian tradition, which attempts as much as possible to "criss-cross" the country ... Burundi is slowly emerging from this tradition; NGO approval procedures remain cumbersome, and until 1993 the government remained reluctant about these initiatives'. Filip Reyntjens, L'Afrique des Grands Lacs en crise: Rwanda-Burundi: 1988-1993 (Paris: Karthala, Les Afriques, 1994), pp. 165-6, translations my own.

After Ndadaye's assassination, Cyprien Ntaryamira was the interim president chosen by political parties in January 1994. On 6 April 1994, Ntaryamira, together with the Rwandan president Juvénal Habyarimana, died in the attack on the presidential aeroplane in Kigali airport, immediately followed by the beginning of the genocide against the Tutsi in Rwanda. On 30 September 1994, a new president was invested in Burundi, Sylvestre Ntibatunganya, who failed to cease the war, and on 26 July 1996 Major Pierre Buyoya seized power.

10 As Palmans notes, 'Due to the economic embargo imposed on the country after the Buyoya coup, the suspension of cooperation and the effects of war, the country has fallen into a state of extreme poverty. Moreover, the Buyoya regime was not in favor of the development of a strong civil society and instead discouraged the creation of associations. Even though fewer associations were created, from 1996 peace began to be discussed, and international organizations, such as UNESCO, Search for Common Ground, and many others, helped in this direction'. Eva Palmans, 'L'évolution de la société civile au Burundi', in Filip Reyntjens and Stefaan Marysse, eds., L'Afrique des Grands Lacs: Annuaire 2005-2006 (Paris: L'Harmattan, 2006), pp. 209-32, here p. 221, translations my own.

11 Reyntjens, L'Afrique des Grands Lacs en crise, p. 256.

12 André Bourque, 'L'aide non étatique au Rwanda: Des leçons de 1994?', Tiers-Monde, 46, 183 (2005), pp. 675-703.

13 See Doctors without Borders in a report published on March 1994, Survie \& FIDH by Jean Carbonare on France 2 in January 1993, UN report in August 1993.

14 About the ambiguous role of NGOs in Rwanda during the genocide and immediately following see Andy Storey, 'Non Neutral Humanitarianism: NGOs and the Rwanda crisis', Development in Practice, 7, 4 (November 1997), pp. 384-94.

15 Nelly Fualdes, 'Classement Doing Business 2018: Le Rwanda confirme son rôle de champion africain', Jeune Afrique, 2 November 2017 at www.jeuneafrique.com/489122/economie/classement-doingbusiness-2018-le-rwanda-confirme-son-role-de-champion-africain, accessed 2 July 2019.

16 Stéphane Ballong, 'Rwanda ou les secrets d'un bon élève', Jeune Afrique, 9 July 2014, at www. jeuneafrique.com/8698/economie/le-rwanda-ou-les-secrets-d-un-bon-l-ve, accessed 2 July 2019.

17 Olivier Caslin, 'Rwanda: Questions sur un champion', Jeune Afrique, 6 September 2017, at www. jeuneafrique.com/mag/468589/economie/rwanda-questions-sur-un-champion, accessed 2 July 2019.

18 Da Silva Florence, 'Le gouvernement rwandais fait le ménage parmi les ONG', Dialogues et Documents pour le Progrès de l'Humanité; Expériences de paix en 1996: engagements de la société civile dans la construction de la paix: éducation, culture, médiation. Retour sur quelques conflits: Rwanda, Tchétchénie, January 1996, at www.irenees.net/bdf_fiche-dph-2211_en.html, accessed 2 July 2019.

19 ICTJ (International Center for Transitional Justice), at www.ictj.org, accessed 14 November 2020.

20 Ibid.

21 Béatrice Pouligny, 'Art, création et dimensions intangibles de la reconstruction individuelle et collective', in Jean-Luc Brackelaire, Marcela Cornejo and Jean Kinable, eds., Violence politique et traumatisme: Processus d'élaboration et de création (Louvain-la-Neuve: Academia L’Harmattan, 2013), pp. 109-27. 
Ibid., p. 110 .

Ibid.

Maëline Le Lay, 'Literary and Artistic Circulations in the Democratic Republic of the Congo, Rwanda and Burundi, from the Belgian Colonial Empire to Africa of the Great Lakes', Artl@ s Bulletin, 5, 2 (2016), pp. $47-8$.

In Kinyarwanda, hagati yacu means 'between us', and ejo n'ejo bundi means 'yesterday, today, tomorrow and the day after tomorrow'.

On his website, International Institute of Political Murder, Milo Rau presents his theoreticalrepresentational artistic research: Milo Rau, 'Reenactment: Probing a Theatrical Concept', at http:// international-institute.de/en/4350-2, accessed 2 July 2019.

Priscilla Wind, 'L'art du reenactment chez Milo Rau', Intermédialités, 28-9 (2017), p. 20.

For example, when Milo Rau came to Rwanda to present Hate Radio, he had the curious idea of broadcasting it on the radio. Doing so not only reactivated trauma but also prompted panic among the audience that the genocide was about to restart. Interview with Assumpta Mugiraneza, IRIBA Center, Kigali, March 2018.

La Benevolencija, at www.labenevolencija.org/la-benevolencija/organisation, accessed 4 May 2020. See Gaëlle Obiégly, 'Une radio contre la fabrique des bourreaux', Libération, 23 March, 2016, at www. liberation.fr/planete/2016/03/23/une-radio-contre-la-fabrique-des-bourreaux_1441581, accessed 2 July 2019. Message 1: when the need for safety is frustrated, people turn to their identity groups to strengthen their feeling of safety. Message 2: when people feel unsafe, they turn to their identity groups and tend to point out the other group as the problem (scapegoat). Message 3: people who intervene to prevent or stop others' mistreatment (active bystanders) give a good example of benevolence and help build a peaceful society. Message 4: treating everyone with equal consideration (humanization) makes violence less likely to arise. Message 5: free exchange between citizens about specific problems encourages diversity of opinions (pluralism) and helps prevent violence. Source: these messages are displayed in La Benevolencija Bukavu office in eastern DRC.

\section{Ervin Staub, Overcoming Evil: Genocide, Violent Conflict and Terrorism (Oxford: Oxford University} Press, 2011).

Email correspondence with Johan Deflander, coordinator of La Benevolencija Amsterdam in January 2018. The La Benevolencia handbook that he kindly gave me goes into more detail. 'One of the central methods used by LB is Entertainment-Education (E \& E) informed primarily by the work of Esta de Fossard (1996; 1998). E \& E is based on the idea that entertainment media formats such as television or radio drama can be used to "package" educational content to positively impact audiences' Knowledge, Attitude and eventually Practice (KAP)'. Media Projects to Empower Populations to Resist Incitement to Mass Atrocity and Stimulate Active Bystandership: A Handbook (n.p., n.d.).

Loffe Chirali Badésiré, Maladie mystérieuse (Paris: Les Phonuscrits des radiophonies, 2009).

Yole!Africa's motto is 'The art of empowering youth'. See https://yoleafrica.org/about-us.

As named in the application to the 2019 Call for DigiTales.

DigiTales across Borders, at https://fr-fr.facebook.com/DigiTalesacross, accessed 1 April 2020.

Eric1key, 'Retour à la terre natale, en force', at www.eric1key.blog/2018/o6/23/retour-a-la-terre-natale-enforce, 23 June 2018, accessed 2 July 2019.

Ibid. The book by Blaise Cendrars referred to is Petits contes nègres pour les enfants des Blancs (Paris: Au 
priority. Gorillas first and always ... The dilemma: engage in the worst conditions or refuse. I take the risk. I'm in. If I do not do it, who will do it? The Ministry of Culture doesn't give a damn! The staff must be in a posh restaurant busy with their belly while the colonizers are in the race for the occupation of the space that remains'. Eric1key, translations my own.

41 'I cannot stand it any more. I leave the room. I am upset. I smoke cannabis. Oh yes, it calms the brains. I refuse to lose my head. I refuse the assholes the power to drive me crazy. My head is all I have. That's all I am'. Ericikey, translations my own.

42 'When I think about it, the genocide and post-genocide consequences affected me in a way I was never able to deal with'. Ericikey, translations my own. For a description of trauma and PTSD in Rwanda see Darius Gishoma and Jean-Luc Brackelaire, 'Quand le corps abrite l'inconcevable: Comment dire le bouleversement dont témoignent les corps au Rwanda?', Cahiers de psychologie clinique, 1, 30 (2008), pp. 159-83.

43 Mimesis here refers to Erich Auerbach's sense of narrative, especially Western literature as the most accomplished form of mimesis. In a joint interview, art sociologist Nathalie Heinich and Jean-Marie Schaeffer exchange their views about art, creation and fiction. Heinich first proposes the distinction between fiction and narrative: 'Nous avons beaucoup insisté, l'un et l'autre, sur la spécificité du fictionnel, en tant qu'il croise la narration et l'imaginaire' ('Both of us have stressed the specificity of the fictional, as crossing the narrative and the imaginary'). Expanding on Nathalie Heinich's distinctions, Jean-Marie Schaeffer adds, 'Ce qui me parait le plus dommageable c'est la confusion récurrente entre fiction et récit: raconter est une des formes canoniques des constructions discursives à prétention factuelle' ('What I think most prejudicial is the frequent confusion between fiction and narrative: storytelling is one of the canonical forms of discursive constructions pretending to be factual'). Jean-Marie Schaeffer and Nathalie Heinich, 'Art, création et fiction: Entre sociologie et philosophie', interview with Annick Louis and Alexandre Prstojevic', Vox Poetica, at www.vox-poetica.org/entretiens/intSchaefferHeinich.html, 19 March 2005, accessed 2 July 2019.

44 Ibid.

45 The DigiTales project was more focused on narrative forms.

46 For a description of Lecomte's work in Africa's Great Lakes see Frédérique Lecomte, Théâtre \& Réconciliation: Méthode pour une pratique théâtrale dans les zones de conflit (Brussels: La Lettre volée, Essais, 2015); and Maëline Le Lay, 'Humanitarian Theatre in the Great Lakes Region: In Pursuit of Performativity', in Chérie Rivers Ndaliko and Samuel Mark Anderson, eds., The Art of Emergency: Aesthetics and Aid in African crises (New York: Oxford University Press, 2020), pp. 229-48.

MAËLINE LE LAY (mlelay@ifra-nairobi.net) is specialized in African literatures. Her research deals with theatre, performing arts and literature in Africa of the Great Lakes Region (DR Congo, Rwanda, Burundi), in (post-) 